\title{
Challenges to Irrigated Crop Zones of Punjab and Sindh Provinces in the Wake of Climate Variability
}

\author{
Faizan ul Hasan, Bareerah Fatima* and Muhammad Ashraf \\ Pakistan Council of Research in Water Resources (PCRWR), Pakistan
}

Submission: January 25, 2021; Published: February 08, 2021

*Corresponding author: Bareerah Fatima, Pakistan Council of Research in Water Resources (PCRWR), Khyaban e Johar, H-8/1, Islamabad- Pakistan

Abstract

Pakistan is an agrarian economy having $60 \%$ irrigated area out of total cultivated area of 30 million hectare. The share of Punjab and Sindh provinces is about $89 \%$ in terms of total irrigated area. Climate change is considered as one of the aggravating factors in present water scarcity situation. There are many model studies which articulates this phenomenon however, no study has ever elucidated in the context of actual data. Therefore, an attempt has been made to visualize the changes in irrigated area, crop cultivation trends, variation in consumptive use and precipitation of 4 major crops. The analyses have revealed no significant variations over a period of 10 year which might cause change in cropped area or crop water requirements. Rather the irrigation system, which is designed on supply based, is able to cater the shocks of possible climate extremes. The analysis of crop water requirement and precipitation of three major crop zones shows few natural aspects of irrigated zones; Firstly, aridity is a common feature in the Indus Basin that include cotton-wheat zones of both provinces and all crops zones of Sindh province. Secondly, irrigation system is designed to meet the water needs of these major crop zones. Thirdly, water availability of winter crop is a challenge because of reduced irrigation supplies and more crop water requirement in crop reaching maturity. Finally, management of irrigation supplies during dry and wet period is more of a governance challenge than a climate variability challenge.

Keywords: Irrigated agriculture; Cropping pattern; Crop water requirement; Climate variability; Evapotranspiration

\section{Introduction}

Agriculture of Pakistan is facing many challenges and climate change is also in consideration as one of the critical challenges of present decade. Water scarcity in irrigated agriculture seems to have aggravated as climate change may substantially impact water consumption patterns. Heavy flooding in rivers and high rainfall intensity during monsoon months may have driven an automated adaptation by the people towards high delta crops instead of predesignated cropping zones. The relative impacts of climate change may be more pronounced in rainfed areas than irrigated areas. The probability of distribution of temperatures may maintain prevalence of average temperature but its variance is high which is going to affect small holder units of biological and agricultural systems [1]. An overview of Global Climate Change Index reports Pakistan as the $5^{\text {th }}$ most vulnerable country to Climate Change. During 2015-2019, Pakistan's position is also dependent upon insured losses to GDP and purchasing price parity [2]. There are several factors behind increasing vulnerability of communities towards climate change, such as increase input prices and scarcity of resources including energy which is also attributed to increasing population [3]. Likewise, since 1961 land use patterns have intensified, leading to an increase in canal irrigated land and excessive utilization of other inputs. As a result, nitrogen fertilizers have contributed into accelerated degradation of land and loss of inland water resources [4]. In irrigated agriculture, impact of climate change may be perceived through changes in cumulative rainfall, evapotranspiration and reducing overall flow in river flows [5]. Increased temperature and heat stress for crops not only increases water requirements of the crops but also affects their yield [6]. In irrigated areas, it is difficult to assess net changes in river flows due to climate change [5]. This relationship is important because $70 \%$ of global fresh water is consumed by agriculture [7]. The study aims to assess variation in the consumptive use of major crops using in-situ climate data. This data is acquired from agrometeorological stations situated in major crop zones.

In South Asian countries, water demand in agriculture is the resultant of multiple cropping patterns. The cropping seasons, Kharif (summer cropping) and Rabi (winter cropping) are dependent upon rainfall at the beginning of cropping season [8]. In case of Pakistan, Indus Basin Irrigation System and groundwater 
abstraction serve crop needs in many areas. Irrigation system is driven by snowmelt which is negatively affected by the reduction in snowfall in Upper Himalayan region as suggested by several studies (Table 1). Substantial research work has been done on predicting climate change impacts on water resources of Indus Basin. All these studies show a high potential for climate extreme such as reduction in snowmelt and increasing temperature are triggering the melting of Himalayan icecaps. The precipitation, however, has remained most unpredictable which is leading to a future of higher inflows in eastern and western rivers [10]. At present, the Indus Basin Irrigation System has a diversion capacity of $128 \mathrm{Bm}^{3}$ whereas $35 \mathrm{Bm}^{3}$ is flowing into sea, unutilized due to inadequate storage [16]. Irrigated agriculture in the command of Indus basin irrigation system is already under stress due to huge supply and demand gaps. Ascertaining climate change's role in widening this gap even further is a challenging task as there are certain other non-climatic drivers behind reducing water availability. Similarly, [8] has found peak water demands in agro-climatic zones of Indo-gigantic basin utilizing MIRCA 2000 database. All of these research have limitation as they offer findings after model studies, mostly of river flows in upper catchments of rivers or satellite-based observations in crop zones.

Table 1: Research studies evaluating climate change and water availability risks for Indus Basin.

\begin{tabular}{|c|c|c|}
\hline Climate Change Assessment Methods & Study Focus & Source (Study Period: 2011-2019) \\
\hline $\begin{array}{l}\text { Assumed virtual stations in Upper Indus Basins, } \\
\text { utilizing data from global precipitation and numeri- } \\
\text { cal models }\end{array}$ & $\begin{array}{l}\text { Precipitation trends in upper Indus Basin as decisive } \\
\text { factor of water availability in rivers }\end{array}$ & [9] \\
\hline $\begin{array}{l}\text { Climate extreme determination in Indus, Ganga and } \\
\text { Barhamputra Basin based on Global Climate Model } \\
\text { (GCM) }\end{array}$ & $\begin{array}{l}\text { Determination climate extreme, temperature and } \\
\text { precipitation between } 1971-2000 \text { and 2071-2100 }\end{array}$ & {$[10]$} \\
\hline $\begin{array}{c}\text { Climate change impact on stream flows, weather } \\
\text { extremes in Upper Indus Basin using Cryospheric } \\
\text { Hydrological model }\end{array}$ & $\begin{array}{l}\text { A comparison of present and future hydrology of } \\
\text { Hunza, Indus, Jhelum and Chenab rivers between } \\
1971-2000 \text { and 2071-2100 }\end{array}$ & {$[11,12]$} \\
\hline $\begin{array}{l}\text { Snow cover changes using Snow cover variation } \\
\text { determination models and satellite produces }\end{array}$ & $\begin{array}{c}\text { Climate Change scenarios and their impacts on } \\
\text { changing Snow cover in Hunza River Basin, a tribu- } \\
\text { tary to Indus River }\end{array}$ & {$[13,14]$} \\
\hline $\begin{array}{l}\text { Climate change risk assessment from top-down } \\
\text { model studies and bottom-up research of regions } \\
\text { directly effected }\end{array}$ & $\begin{array}{l}\text { A climate change risk assessment approach for } \\
\text { climate change vulnerable regions }\end{array}$ & {$[15]$} \\
\hline $\begin{array}{l}\text { LPjmL model used for determining impact of } \\
\text { climate change for water availability for crop } \\
\text { production }\end{array}$ & $\begin{array}{l}\text { Annual crop water requirements in South Asian } \\
\text { region under the impact of climate change }\end{array}$ & [8] \\
\hline
\end{tabular}

Agriculture consumes a large share of global freshwater resources by virtue of hydraulic infrastructure, irrigated agriculture remains undisturbed from climate variability. This scenario is not going to prevail for long due to increasing population and socio-economic development pressures on existing water resources [17]. Likewise, in Pakistan, the national storage of only 28 days is under stress to regulate the canal irrigation system on perennial basis. Potential climate change in addition to deficit in surface water resources is going to multiply stress on irrigated agriculture of Pakistan. Besides, the country has experienced some extreme floods and rainfall events in the hilly region causing enormous damage to crops and farmers livelihood [6]. The events of large floods have caused massive damage and loss to hydraulic infrastructure widely spread in the country, which is also a consequence of extreme climate event such as heavier than normal rainfall. However, at farm level where flow regime does not change, there is a need to critically evaluate variations in crop water requirements as a result of such climate events. In an analytical research on farmers' perception on climate change, [18] have concluded that having prior knowledge on climate change, farmers are more likely to perceive hotter temperatures and more irrigation requirements. It is quite possible that in Pakistan, the real reasons of irrigation supply and demand gaps are being ignored in the hue and cry of climate change. This paper analyses level of water stress by determining consumptive use of crops and rainfall variability over last decade (2007-17) in major crop zones of Punjab and Sindh provinces.

\section{Study Area}

Agriculture in Pakistan is divided into two cropping seasons, Kharif (May-October) and Rabi (November-April). Canal water is also distributed according to this segregation. The gross command area of Indus Basin Irrigation System is 16.85Mha [16], mostly lying in Punjab and Sindh provinces. In the irrigated plains of these provinces, generally a mixed cropping pattern prevails, dominantly; cotton-wheat, rice-wheat and sugarcane mix. The total irrigated area of Punjab province is $7.8 \mathrm{Mh}$ a that comes under the command of 25 main canals sourced from 2 reservoirs, 7 barrages / headworks. In Sindh Province, a command area of 5.3Mha is irrigated by a network of three barrages and 14 canal systems. Annual canal water withdrawal below rim station for Punjab and Sindh province are 63.27 and $52.70 \mathrm{Bm}^{3}$ 
respectively. The irrigated area is counted twice for planning purposes according to cropping seasons and the command area is not entirely irrigated. Both of these provinces are densely populated; Punjab (110 million) Sindh (47.89 million) [19]. Land use intensification on canal irrigated land is very much obvious to meet the food and livelihood needs of huge population dependent upon these land and water resources. In this study, 3 major crops zones which forms most of the irrigated agricultural land of the country; Cotton-wheat (48\%), Rice-Wheat (16.72\%) and Sugarcane mix (3.82\%) [20] have been studied. The climatic data for years 2007-17 is selected for analysis because of no significant variations in the seed varieties and cultivation practices of farmers during this period. It is very much important to make these assumptions given the expense of cropping zones being studied.

Irrigated crop zones are demarcated according to soilpotential, climate and availability of irrigation supplies (Figure 1). Cotton-Wheat zone forms the largest part of country and maintains dry and arid climate. Irrigation supplies are ensured because groundwater is either too deep or highly saline. This zone lies in South of the Punjab province and is situated on left bank of the Indus River and on the upper part of the Sindh province. Central and North-East zone of Punjab zone is regarded as Sugarcane Mix zone and Rice-Wheat zone. The sugarcane mix zone is mostly situated in that part of irrigation canal command that have both sufficient canal water supplies and fertile soil.

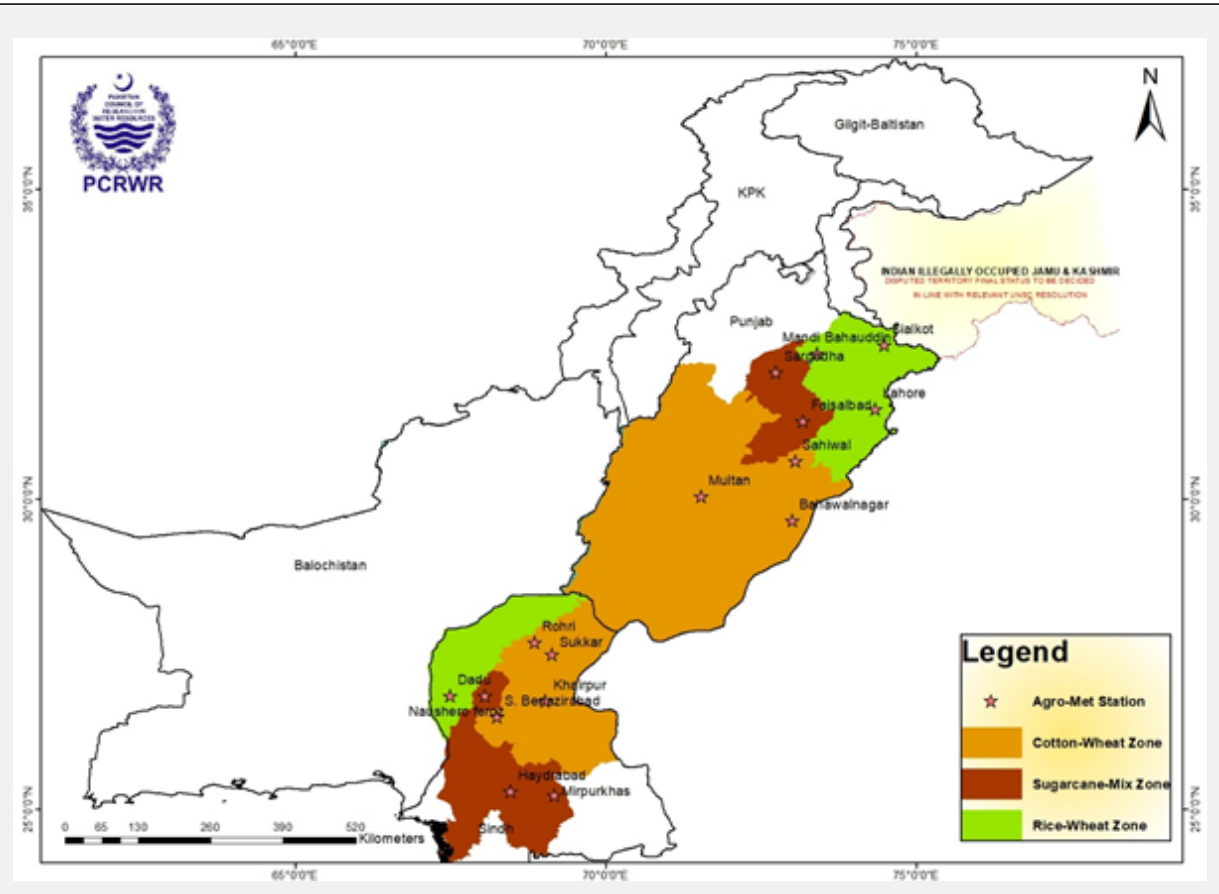

Figure 1: Location of studied cropping zones of Punjab and Sindh provinces of Pakistan.

Normal climate of Punjab province is subtropical, where summer temperature crosses $45^{\circ} \mathrm{C}$ and winter temperature fall as low as $0^{\circ} \mathrm{C}$. Cumulative average rainfall in the province is $400 \mathrm{~mm}$ [21]. Climate of Sindh province is also subtropical, average annual rainfall reaches to $200 \mathrm{~mm}$ at maximum site, during summer season temperature crosses $46^{\circ} \mathrm{C}$ and lowers to $2^{\circ} \mathrm{C}$ in winters [22]. Crop zones in Sindh are fairly distinguished by left bank and right bank of the Indus Basin. Left bank is a combination of cotton-wheat zone and sugarcane mix zone whereas the right bank is singularly the rice-wheat zone [21]. Sindh crop zones are distinguished for shallow groundwater table ranging up to 3 meters. Studies have revealed that in fresh groundwater quality zones, crops such as Sugarcane, Rice, Wheat and Cotton consumes groundwater [22]. Cotton-Wheat zones expands to dry climate districts up to desert climate whereas Sugarcane mix zone is a central part of the province where canal water supply is perennial supplemented with fresh groundwater zone for proximity to
Indus river.

Data and Methods

\section{Data source}

Primary data of temperature, precipitation and reference Evapotranspiration ( $\mathrm{ET}_{0}$ ) is acquired from the agro-met stations of Pakistan Meteorological Department (PMD) located in major crop zones of Punjab and Sindh provinces for a study duration between 2007 and 2017. Canal irrigated crop zones under the study and their reference agro-met stations are illustrated in Table 2.

A total of 17 stations are representing approximately 17.27Mha of gross command area. The data on actual cropwater requirement is estimated through drainage type lysimeter stations of Pakistan Council of Research in Water Resources (PCRWR) located in Central Punjab and in Sindh Provinces. Crop evapotranspiration coefficient $(\mathrm{Kc})$ values are used to determine 
crop water consumed by the crops and respective variation under climatic conditions. Other data viz. land use, canal command area in the major crop zones is acquired from the published provincial Punjab. development statistics record.

Table 2: Reference agro-met stations in major crop zones of Sindh and

\begin{tabular}{|c|c|c|}
\hline Zone & Sindh & Punjab \\
\hline Cotton-Wheat Zone & Larkana, Rohri, Sakrand and Khairpur & Bahawalpur, Multan, Jhang, Sahiwal \\
\hline Rice-wheat zone & Dadu, Larkana & Faisalabad, Sialkot, Lahore, Mandi Bahauddin \\
\hline Sugarcane mix & Padidan, Mirpurkhas, Tandojam & Sargodha \\
\hline
\end{tabular}

\section{Methods}

Climate change impacts in irrigated areas of Punjab and Sindh provinces may increase crop water requirement by increasing temperature and reducing volumes of precipitation. Due to this deficit in water availability, irrigated area may reduce. Therefore, an analysis of change in irrigated area during study period 200717 was undertaken. An assessment of coverage of four main crops; wheat, rice, sugarcane and cotton was also conducted to point out any type of variability.

In every cropping zone, there is located one or more agromet stations to record the values of precipitation, temperature and evapotranspiration. Cropping zones are large and spans over many districts therefore more than one agro-met stations exist in a single crop zone. Therefore, variability analysis is conducted by plotting the values of each stations into box plots indicating extent of change in a particular month during 2007-17. Crop water requirement or $\mathrm{ET}_{\mathrm{c}}$ is calculated using the values of $\mathrm{Kc}$ of a particular crop in a cropping zone using the following formula:

$$
E T_{c}=K c \times E T_{o}
$$

Where, $\mathrm{ET}_{\mathrm{c}}$ is a crop water requirement of a particular crop in a specific region whereas $K_{c}$ is the value of crop coefficient of that particular crop. $\mathrm{ET}_{\mathrm{o}}$ is a reference evapotranspiration value and historical values are taken to estimate changes in crop water requirements over the study period. Both precipitation and crop evapotranspiration are determinant of variations in crop water requirement and consequent stress on water resources $[5,6]$. The estimation of crop water requirement of a crop during specific cropping month is the determinant of temperature and reference evapotranspiration. Seasonal average of daily crop water requirement is calculated using equation (1).

\section{Results and Discussion}

\section{Changes in cropping patterns}

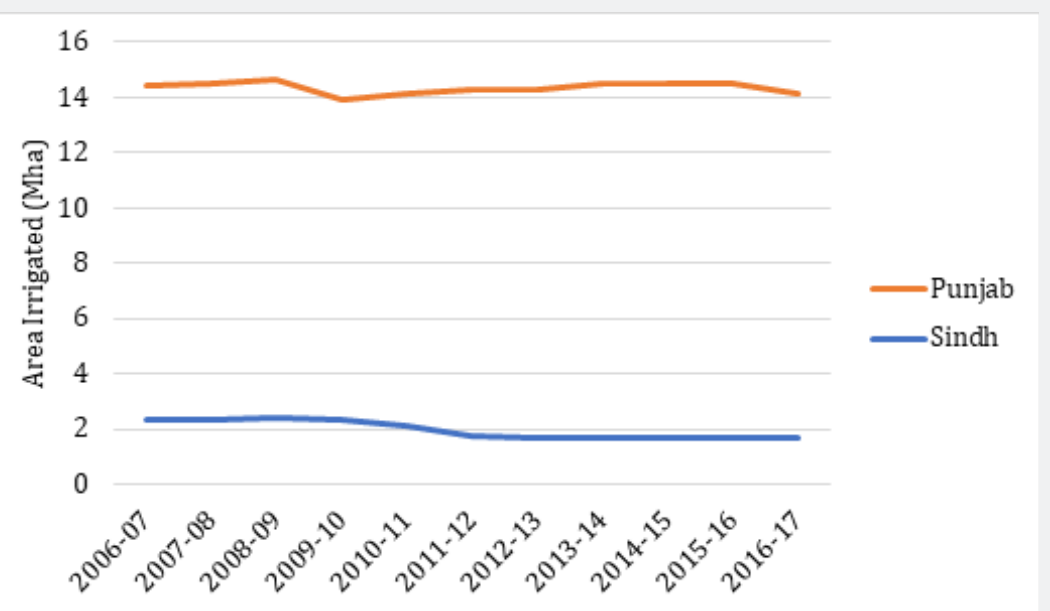

Figure 2: Changes in irrigated area (including tube well irrigated).

Source: [29].

In canal irrigation system of Indus Basin, canal water allowance is fixed over a thousand acres (404ha) whereas crop cultivation choices are shifting. Indus basin irrigation system is supply based, which means canal water supplies are not according to crop water requirements [23]. This irrigation system which was initially designed for a cropping intensity of 50 or $70 \%$ 
(100 years) reached to an average cropping intensity of $120 \%$ [24]. This scenario has also increased pressure on canal irrigation supplies during monsoon period in Kharif and dry period in Rabi season. Increase in agricultural land has been occurred at an average rate of $1 \%$ during 1992 to 2008 . This increase has been supplemented by increasing number of tube wells, but canal water supplies remained important [25]. The changes in area under irrigation from irrigation sources such as canal irrigated, tube wells, canal tube wells and canal wells have been assessed for the total irrigated area (Figure 2).

Irrigated area varied less significantly over 10-year study period in both the provinces. In Punjab province, irrigated area remained higher than that of Sindh province. Surface water resources are dependent upon river inflows and precipitation during monsoon (summer) months. In canals, access water is available during Kharif period whereas Rabi season is dependant upon the network of storage reservoir or rainfall. A shift in rainfall during Rabi season (winter) months may become a challenge for wheat crop, a basic food staple for Pakistan. During Kharif season, water intensive crops such as Cotton and Rice are grown in most of the irrigated zones of the country. Sugarcane is also a high delta crop which is perennial and mostly sown during the month of October or March. Therefore, this crop withdraws its share of water along both Rabi and Kharif crops. Variations in irrigation water supplies must have an effect on crop choice of farmers (Figure 3).

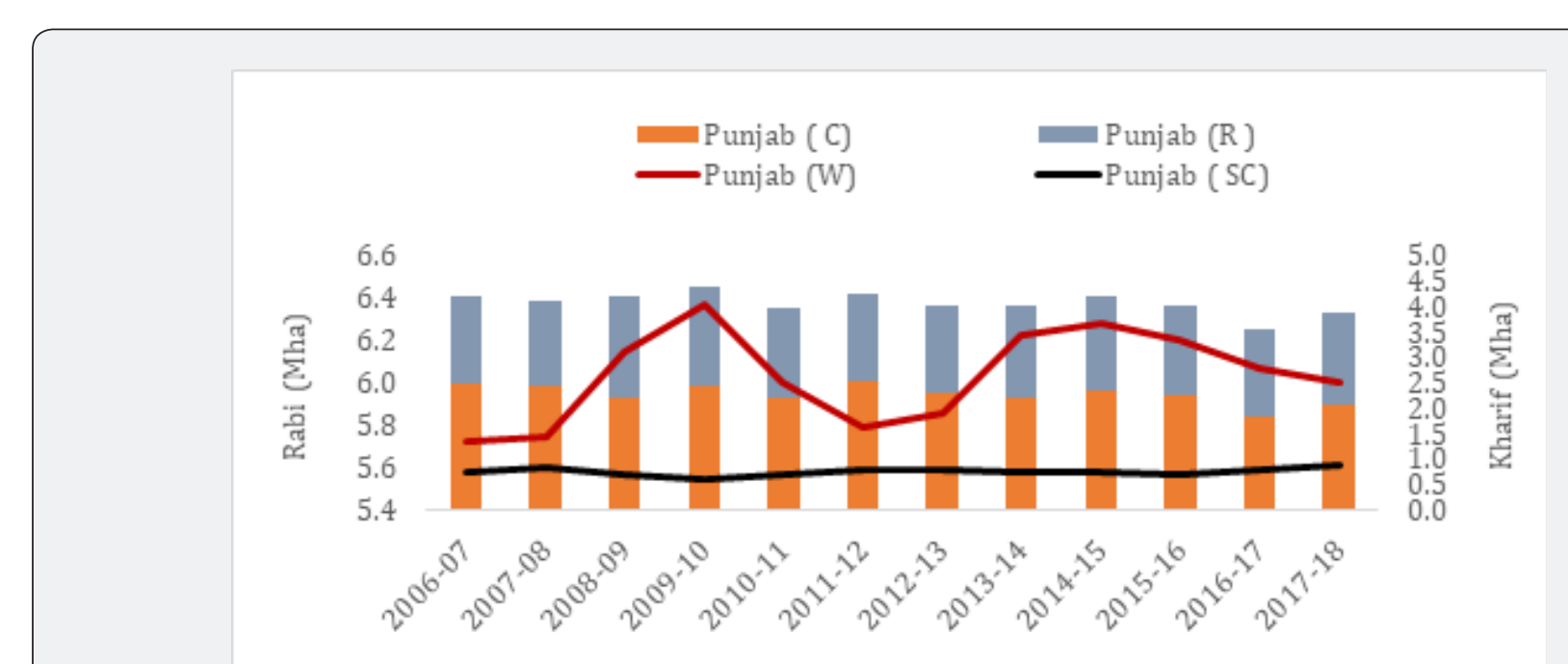

Figure 3: Changes in crop cultivation trends in Punjab province.

Source: [29].

In Punjab province, Wheat crop (W) witnessed the most variations as a major Rabi crop over the study period. However, the choice of Sugarcane (SC) has not shown any significant change. Rice (R) and Cotton crops (C) have followed the same trend in their respective zones, for instance, in year 2016-17 both rice and cotton crops were slightly less compared to the earlier year. It is essential to mention here that Rice-Wheat zone of Punjab province includes northern districts of the province whereas cotton zone is mostly dry southern part. Wheat is not a water intensive crop rather a major crop having low support price, 10 year average price of wheat grain is US $\$ 7$ for $40 \mathrm{~kg}$ bag, exceeds the unit cost of production [19]. Variations in crop preference may have shifted out of economic reasons. Rice, Cotton and Sugarcane are high value crops compared to Wheat therefore their preference have not changed significantly. This situation shows no variations in crop choices to less water availability in Punjab province. A similar trend has been observed in Sindh province.

Only few exceptions of districts cultivate both cotton and Rice crop at the same location in Sindh province. Such choice of cropping is certainly out of cropping zone which also enhance pressure on irrigation water supplies. In Sindh province (Figure 4), Sugarcane, Rice and Wheat crop followed the same trend whereas cotton crop has shown some variations, for instance in year 2011-2012, cotton cultivation was the lowest for the studied period. In year 2010-11, least of Rice and Cotton crop has been witnessed which is actually the onset of 2010 historical flood in Indus Basin during the Kharif season which is also the cultivation period of both of these crops. No significant change in overall crop share in Sindh and Punjab provinces in comparison reducing irrigated area coverage. Prevalence of water intensive crops during Kharif season is associated with conducive climate for the crop and relatively higher volume of irrigation supplies. Whereas shortage in irrigation supplies has always remained common for winter crops.

\section{Variations of crop evapotranspiration and precipitation}

Stress on irrigation system may only be determined by the supply and demand gap. Figure 5 shows variations in 
consumptive use of Wheat and Cotton crops in Sindh and Punjab provinces. Wheat season starts from the month of November and ends in March. Cotton season begins in May and last till mid of October every year in the Cotton-Wheat zones of both provinces. No significant change has been observed in the consumptive use of Wheat crop during the season, except slight variations in March in both provinces. Cotton crop has shown a daily increase in consumptive use during June and July months, ranging between $0.66 \mathrm{~mm} /$ day to $0.9 \mathrm{~mm} /$ day. This slight change is more pronounced if estimated in the context of area under a particular crop. A slight daily increase in consumptive use of cotton crop may cause a significant increase in water demand over a thousand hectare. This increase in water demand is met with canal water supplies and monsoon rainfall as shown in Figure 6. Canal water supplies are available at a fixed rotation against lesser crop water requirements. The average annual ratio of canal water supply to crop water requirements range between 0.41 to 1.41 [26]. This difference in supply to requirement ratio occurs due to the type of canal (perennial, non-perennial)., quality of groundwater in canal command, average annual precipitation and type of crop grown in a canal command.

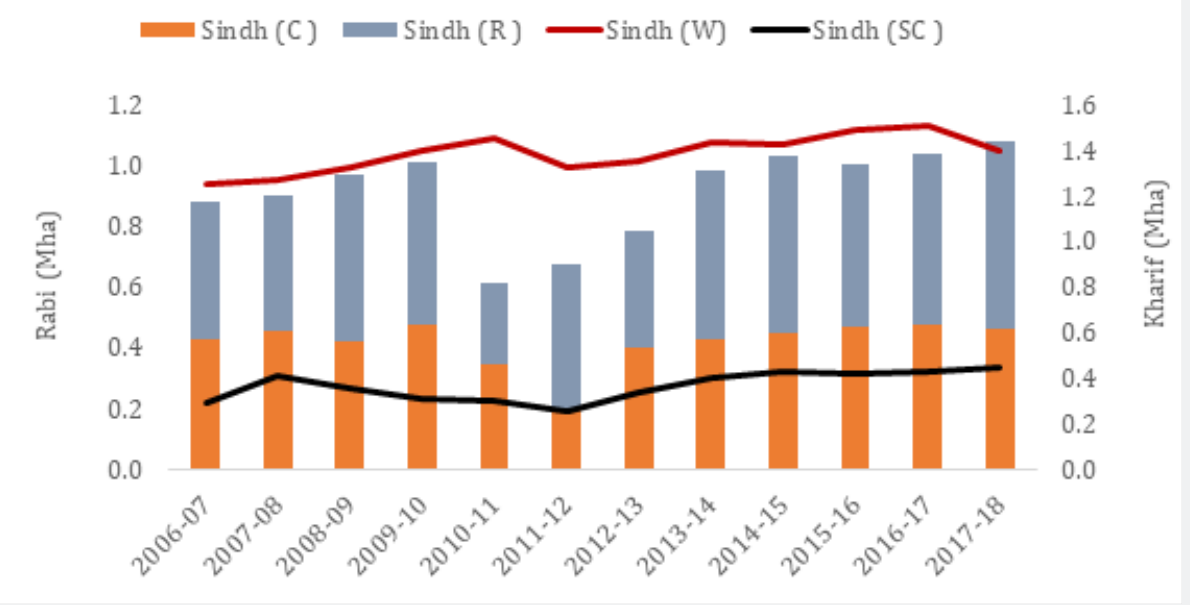

Figure 4: Variations in crop cultivation trends in Sindh province.

Source: [29].

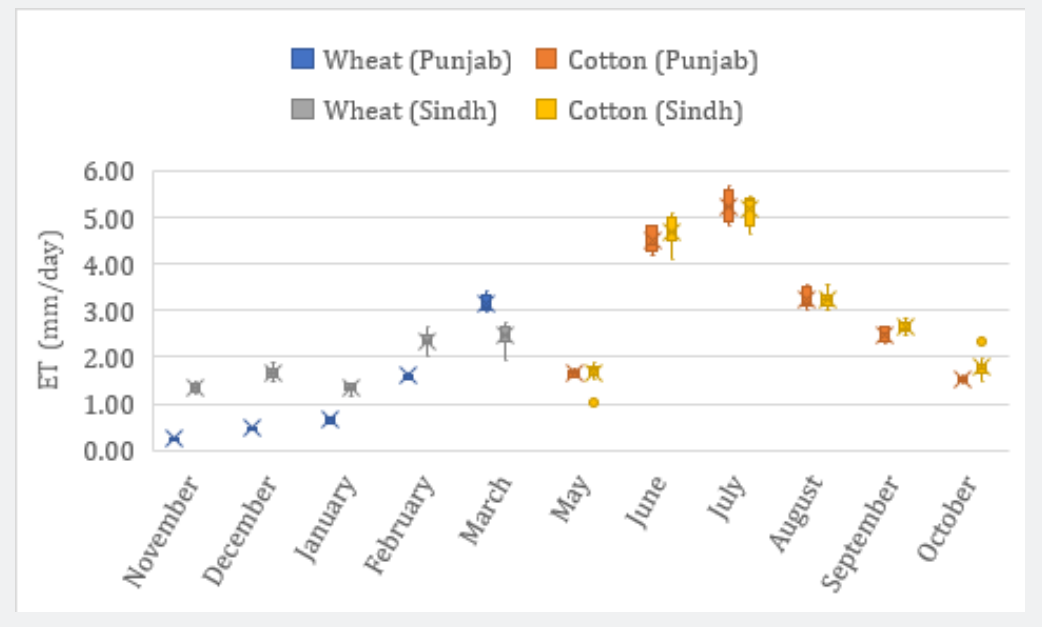

Figure 5: Crop water requirement variations in Cotton-Wheat zone.

Cotton-wheat zones are extensively irrigated crop zones in both of the studied provinces. During the months of June and July, the crop water requirement is the highest which is also synchronized with monsoon rainfall season. Pakistan receives
$85 \%$ of its surface water supplies during summer monsoon periods starting by the mid of June towards the end of August every year. High rainfall trend, as shown in Figure 6, is natural for all crop zones of Pakistan. 


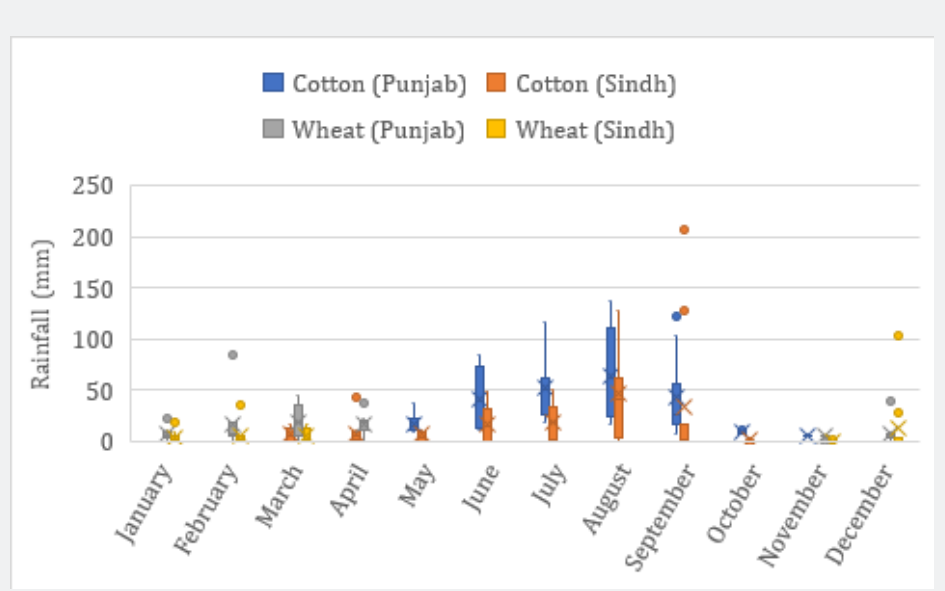

Figure 6: Seasonal precipitation variations in Cotton-Wheat zones.

The variability of rainfall events over the span of JuneSeptember months in cotton-wheat crop zones are point of concern. For instance, in Sindh province, accumulative rainfall exceeding $200 \mathrm{~mm}$ in a month may be harmful for cotton due to its near maturity stage in the month of September. Likewise, in Punjab province, high rainfall variability is also observed starting from June to September. High precipitation variability is also witnessed during March month in Punjab cotton-wheat zone. In this month, the Wheat crop of that particular zone is at ripening stage may pose higher implications in form of lower yield of key food crop. During winter months rainfall follows the same pattern slightly higher in Punjab province. This is perhaps due to the reason that winter rainfall is caused due to westerly disturbance of wind that travel through Sindh province to Punjab province. However, 5-month summer crop of cotton enjoys more supplemental rainfall due to monsoon period. Situation for crop becomes critical on farm level because abundance of irrigation supplies as well as on farm precipitation available to irrigate cotton crop, posing a big water governance challenge for irrigation system managers and water management challenge for farmer at farm level.

Rice-Wheat zones of Punjab and Sindh provinces are geographically distinct from Cotton-Wheatzones. A common factor in these districts is winter Wheat crop which is understandable as a result of limited irrigation supplies during Rabi season. There is a versatility in crop water requirements and types of varieties sown. The evaluated water requirement of Rice crop is $500 \mathrm{~mm}$ in Punjab province and $1100 \mathrm{~mm}$ in Sindh province [22,27]. No significant variation in average daily crop water requirements over a month has been observed except for a Rice crop in Sindh. Figure 7 shows no overall variation in consumptive use of crop.

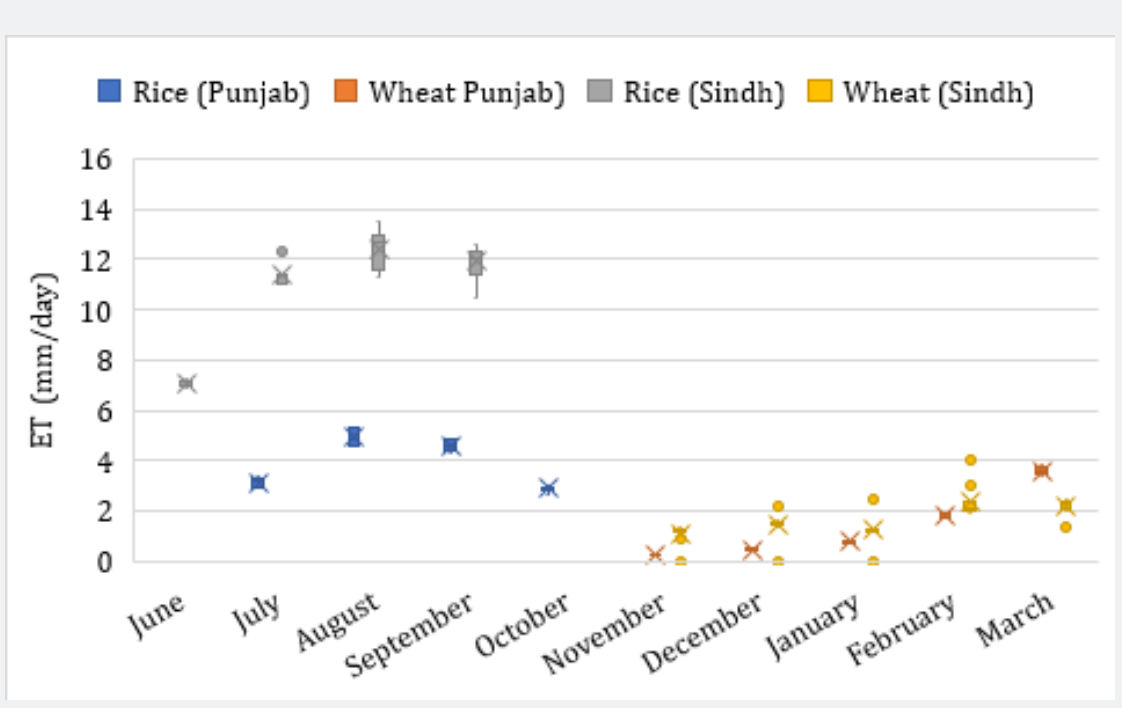

Figure 7: Crop water requirement variations in Rice Wheat zone. 
Similar to Cotton-Wheat crop zone, there is a high variability of rainfall events in Rice-Wheat zone of Punjab province even during monsoon season (Figure 8). No change in rainfall pattern observed during the studied period in Rice-Wheat zone of Sindh province. Increased winter rainfall in Rice-Wheat zone is also a pronounced phenomenon. This climate scenario may become an opportunity for providing relief to irrigation system during winter months and a challenge if temporal distribution of precipitation if not in favour of crop stage.

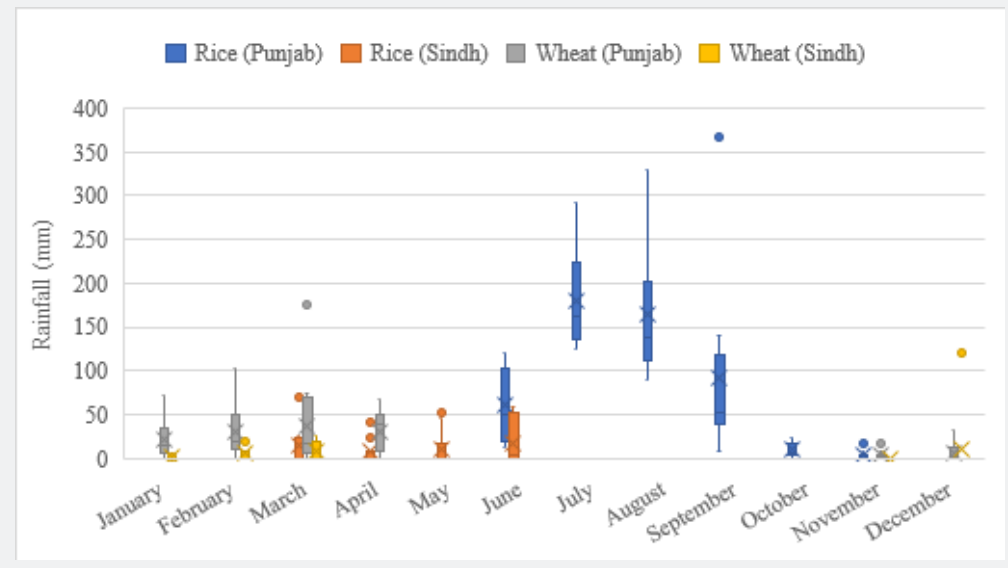

Figure 8: Seasonal precipitation variation in Rice-Wheat zones.

Sugarcane crop in both of the provinces spans over one complete year consuming much of irrigation supplies throughout the year. The crop water requirement of Sugarcane crop also varies for both Sindh and Punjab, $2000 \mathrm{~mm}$ and $1500 \mathrm{~mm}$ respectively. In both of these provinces, sugarcane mix zone exists in various combinations; Sugarcane with Maize, rice, banana, grams sometimes cotton as well [20]. A majority of these combination crops are high water consuming, but Sugarcane consumes most of water for being yearlong crop. The consumptive use of sugarcane crop varies more significantly during summer/monsoon months (Figure 9). This change in consumptive use is higher in Punjab and lesser in Sindh province.

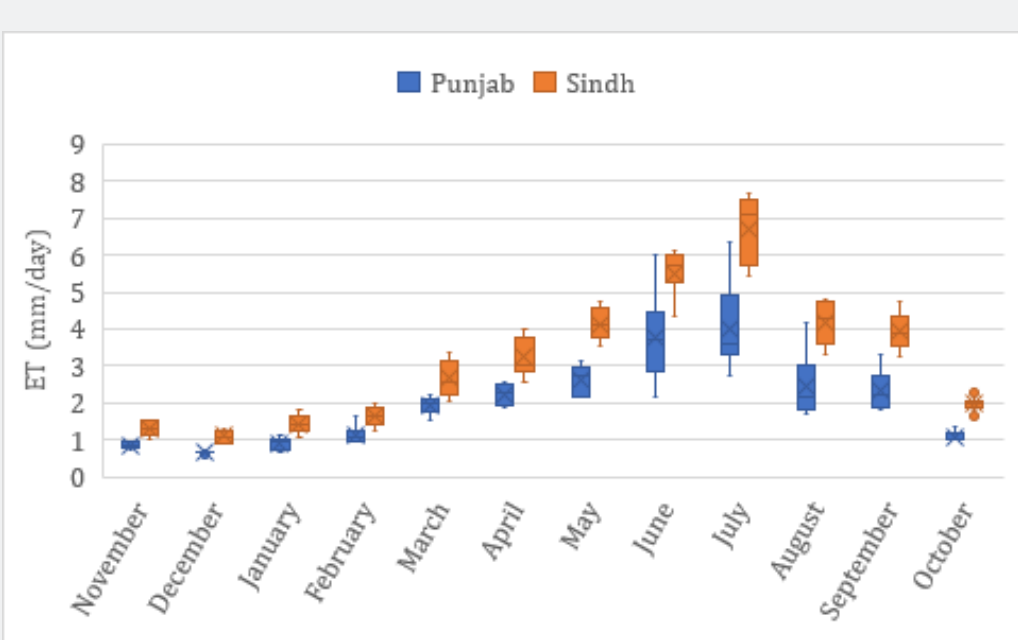

Figure 9: Crop water requirement variations in Sugarcane mix zone.

Monthly rainfall also varies in both provinces during the study period. In Punjab provinces during winter months, high rainfall events are recorded in February, March and April during the study period (Figure 10). No change is observed in Sindh province during the winter months. However, in summer/monsoon months variations in monthly rainfall is high, more summer rains fall in Punjab province compared to Sindh province. These rainfall events have balanced the variations in consumptive use of crops. 
Moreover, Sugarcane crop is not vulnerable to heavy rainfall and sustains flooding unlike cotton crop. Rainfall frequency is low in winter months parallel to low canal water availability. This cycle of surface water supply is fixed and rainfall distribution is entirely natural. In the context of climate variability, monthly variations during 2007-17 during the study period.

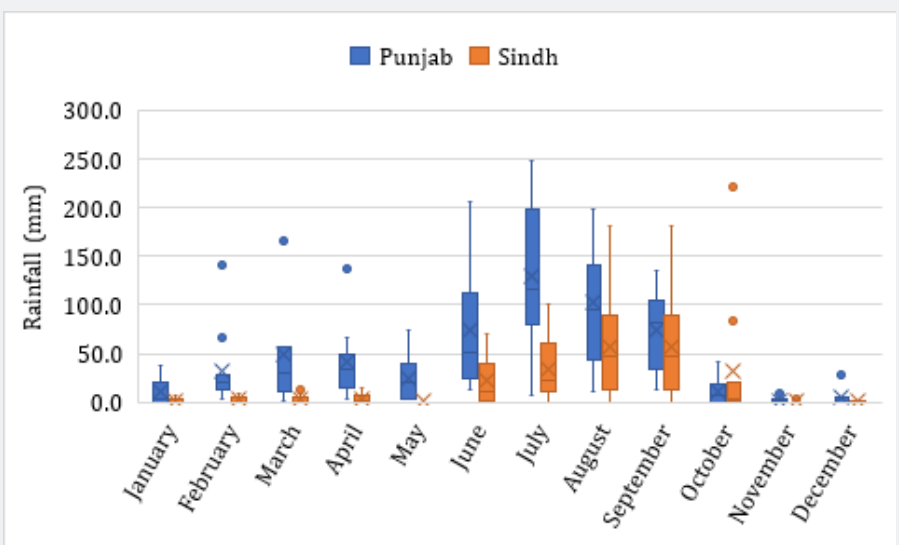

Figure 10: Seasonal variations in precipitation for Sugarcane mix zone.

\section{Crop water consumed by major crops}

In irrigated agriculture, increase in crop water requirement and consequent stress on irrigated agriculture deemed as a measure of climate change or climate variability [5]. Temperature is a main driver of climate change which also influences the speed of wind current carrying clouds and in perspective of agriculture, evapotranspiration [28]. In this respect, climate variability in the studied crop zones has been observed during years 200717 (Figures 5-10) and some changes in this relatively short observation period has been observed crop season-wise. Average daily crop water requirement of four major crops (Cotton, Wheat, Sugarcane and Rice) has been analysed which are also the crops of high-water requirement except for Wheat. Climate variability may be observed from a scenario of receiving rainfall event during month of March. In other words, rainfall is not synchronized with crop water requirement according to its stage. In retrospect, during monsoon high localized and basin-wise rainfall is received. Although consumptive use of summer crop is high during monsoon months but due to heavy rainfall, crops are least dependent upon canal water supply. A change in rainfall volume within monsoon has diverse impact on crop health according to its type.

Crop water requirement estimates are made on the basis of season and length of seasons vary between Sindh and Punjab provinces. For instance, Wheat is Rabi crop and its season spans over mid of November to April in Punjab province [27], whereas for Sindh province it starts in mid of November and ends in March [22]. Despite this difference in length of season, Wheat crop consumes more water in Sindh province as compared to Punjab province. In Rice-Wheat zones, both crops have less daily water requirements due to lower value of $\mathrm{ET}_{\mathrm{o}}$ in their respective crop zones. The average length of season for Cotton crop is same for both of these provinces because Cotton-Wheat zones of Punjab and Sindh provinces are geographically adjacent. Due to this reason, there is not much difference in daily water requirements of Wheat crop in Cotton-Wheat zones of both provinces. Wheat crop during winter months is more reliant upon irrigation system.

Sugarcane mix zone represent similar characteristics in both of these provinces; mix cropping of vegetable and fruit crops [21] which is an indicator of high vegetative cover and abundance of freshwater resources. In Punjab province, precipitation events significantly supplement crop water requirement particularly during monsoon months. In Sindh province, however, due to its higher aridity compared to Punjab province, reliance on irrigation system is higher compared to Punjab province.

\section{Conclusion}

Climate change poses serious risks to human security, food and water security particularly for nations dependent upon major irrigation systems such as Indus Basin. Many studies have suggested and forecasted changes in Upper Indus Basin, reducing snowmelt, less events of rain, and high events of torrential rains causing soil erosion. These changes are certainly going to affect irrigation supplies fed by Indus Basin irrigation system which gives life to fertile land of Punjab and Sindh provinces. Key idea behind this research was to estimate potential water stress in irrigated areas by variations in three agro-met parameters viz. precipitation and consumptive use of crops over a decade. During the study period, no significant change has been observed in overall irrigated land and coverage of four major crops. A significant variation in consumptive use of Cotton and Sugarcane crops was 
observed during summer months in all studied crop zones of two provinces. Precipitation variability is high during late winter months, February-April. Increasing trend in precipitation during maturity months of Cotton and Wheat crops post potential threat to the yield of these two key crops, socio-economics of CottonWheat zone of Punjab and above all food security of the nation. High precipitation variability during monsoon/Kharif period in Sugarcane mix zone and Rice-Wheat zones have not posed potential threat as yet. Therefore, based upon the meteorological observations, the phenomenon of climate variability cannot be ruled out. Whereas the stress on canal water supplies is prevailing ever since the beginning of irrigation system. Fortunately, variations in precipitation and consumptive use of major crops are inclined with natural situation. Therefore, climate variability cannot be ruled out as it is causing several crop managements challenges.

\section{Acknowledgment}

The support of Global Change Impact Studies Centre (GCISC) Ministry of Climate Change is acknowledged for undertaking this research.

\section{References}

1. Thornton KP, Ericksen PJ, Herrero M, Challinor AJ (2014) Climate variability and vulnerability to climate change: a review. Global Change Biology 20(11): 3313-3328.

2. Eckstein D, Hutfils ML, Winges M (2019) Global climate risk index 2019. German Watch.

3. Abbasi SS, Ahmad B, Ali MA, Anwar MZ, Dahri ZH, et al. (2017) The Indus Basin: A glacier-fed lifeline for Pakistan. HI-AWARE Working Paper 11. Kathmandu: HI-AWARE.

4. Arneth A, Denton F, Agus F, Elbehri A, Erb KH, et al. (2019) Framing and Context. In Climate Change and Land: an IPCC special report on climate change, desertification, land degradation, sustainable land management, food security, and greenhouse gas fluxes in terrestria ecosystems, pp. 1-98.

5. Tubiello FN, Velde MV (2011) Land water use options for climate change adaption and mitigation in agriculture. The state of the world's land and water resources for food and agriculture (SOLAW). Managing syst at risk, p. 38.

6. Ali A, Erenstein O (2017) Assessing farmer use of climate change adaptation practices and impacts on food security and poverty in Pakistan. Climate Risk Mgmt 16:183-194.

7. Woznicki SA, Nejadhashemi AP (2015) Climate change and irrigation demand: Uncertainty and adaptation. J Hydrol Regl Std 3: 247-264.

8. Biemans H, Siderius C, Mishra A, Ahmad B (2016) Crop-specific seasonal estimates of irrigation-water demand in South Asia. Hydrol Earth Syst Sci 16: 1971-1982.

9. Hussain, ZD, Ludwig F, Moors E, Ahmad B, Khan A, et al. (2016) An appraisal of precipitation distribution in the high-altitude catchments of the Indus basin. Science of the Total Environment 548-549: 289-306.

10. Lutz AF, Immerzeel WW, Kraaijenenbrink PDA, Shrestha AB, Bierkens, MFP (2016) Climate Change Impacts on the Upper Indus Hydrology : Sources, Shifts and Extremes. PLOS one 11(11): e0165630.
11. Lutz, AF, Herbert W, Biemens H, Shrestha AB, Wester P, et al. (2016) Selecting representative climate models for climate change impact studies: an advanced envelope-based selection approach. Intl J Climatol 36(12): 3988-4005.

12. Lutz AF, Immerzeel WW, Sherstha AB, Bierkens MFP (2014) Consistent increase in High Asia 's runoff due to increasing glacier melt and precipitation. Nature: Climate Change 4: 587-592.

13. Tahir AA, Chevallier P, Arnaud Y, Ahmad B (2011) Snow cover dynamics and hydrological regime of the Hunza River basin Karakoram Range Northern Pakistan. Hydrol Earth Syst Sci 15: 2275-2290.

14. Collier E, Maussion F, Nicholson LI, Molg T, Immerzel WW, et al. (2015) Impact of debris cover on glacier ablation and atmosphere - glacier feedbacks in the Karakoram. The Chryosphere 16: 1617-1632.

15. Conway D, Nicholls RJ, Brown S, Tebboth MGL, Adger WN, et al. (2019) Risks and adaptation in climate-sensitive regions. Nature Climate Change.

16. Qureshi SA (2011) Water Management in the Indus Basin in Pakistan: Challenges and Opportunities 31(3): 252-260.

17. Iglesias A, Garrote, L (2015) Adaptation strategies for agricultural water management under climate change in Europe. Agricultural Water Management 155: 113-124.

18. Niles MT, Mueller ND (2016) Farmer perceptions of climate change: Associations with observed temperature and precipitation trends irrigation and climate beliefs. Global Entl Chge 39: 133-142.

19. Pakistan Bureau of Statistics (2017) Population Census of Pakistan 2017. Islamabad. Pakistan.

20. MoE (Ministy of Environment) (2009) Land use Atlas of Pakistan. National Land use plan project. Islamabad, Pakistan.

21. FAO (Food and Agriculture Organization) (2017) Rabi Crop Mask Punjab and Sind Pakistan. Italy Rome.

22. Rao MA, Ashraf M, Bhatti AZ, Salam HA, Gul N (2016) Water Requirements of Major Crops in Sindh. Pakistan Council of Research in Water Resources (PCRWR). 88 Islamabad, Pakistan.

23. Tahir Z, Habib Z (2000) Land and Water Productivity: Trends across Punjab canal commands. Working paper 14: 35. International Water Management Institute (IWMI).

24. Randhawa HA (2005) Water development for irrigated agriculture in Pakistan: past trends, returns and future requirements.

25. Yu W, Yang Y, Savitsky A, Alfold D, Brown C, et al. (2013) The Indus Basin of Pakistan: The Impacts of Climate Risks on Water and Agriculture. ( $1^{\text {st }}$ edn), Washington DC.: World Bank.

26. Bandaragoda DJ, Rehman (1995) Warabandi in Pakistan's canal irrigation systems: Widening gap between theory and practice. Colombo, Lanka: International Management Institute. Country Paper, Pakistan No. 7: 89.

27. Soomro, ZA, Ashraf M, Ejaz K, Bhatti AZ (2018) Water requirements of Major Crops Central Punjab. Pakistan Council of Research in Water Resources (PCRWR). 44 Islamabad Pakistan.

28. IPCC (2007) Climate Change 2007 Synthesis Report, Intergovernmental Panel on Climate Change. International Panel of Climate Change.

29. MoFSR (Ministry of Food Security and Research) (2018) Agricultural Statistics 2017-18, Islamabad, Pakistan. 

CC Comons Attribution 4.0 License BY

DOI:10.19080/IJESNR.2021.27.556207
Your next submission with Juniper Publishers will reach you the below assets

- Quality Editorial service

- Swift Peer Review

- Reprints availability

- E-prints Service

- Manuscript Podcast for convenient understanding

- Global attainment for your research

- Manuscript accessibility in different formats ( Pdf, E-pub, Full Text, Audio)

- Unceasing customer service

Track the below URL for one-step submission https://juniperpublishers.com/online-submission.php 